\title{
MENAKAR PROGRESIVITAS TEKNOLOGI FINANSIAL (FINTECH) DALAM HUKUM BISNIS DI INDONESIA ${ }^{1}$
}

\author{
Mariske Myeke Tampi \\ (Dosen pada Fakultas Hukum Universitas Tarumanagara. Memperoleh gelar Sarjana Hukum (S.H.) dari Universitas \\ Diponegoro (2008), Magister Hukum (M.H.) dari Universitas Kristen Satya Wacana (2012)) \\ (E-mail: marisket@fh.untar.ac.id)
}

Received: 22 Oktober 2018; Accepted: 27 Mei 2019; Published: 30 Juni 2019

\begin{abstract}
:
The PBI Number 19/12/PBI/2017 concerning the Implementation of Financial Technology is a staple of policy that shows the Financial Technology (Fintech) has been allowed to exist in Business Law in Indonesia such as business to business and business to consumer with particular limitation. The regulation on electronic money that has been enacted before the issuance of PBI Number 19/12/PBI/2017 is also included in the definition of Financial Technology (Fintech) in PBI Number 19/12/PBI/2017. Enormous benefits from Financial Technology (Fintech) is a driving force of the progressivity of the Financial Technology (Fintech) regulation. Review of laws relating to Financial Technology (Fintech) in Indonesia illustrates that the policy of Financial Technology (Fintech) is quite progressive. Such progressivity may be examined from the view point of Satjipto Rahardjo's progressive law theory and Roscoe Pound's sociological jurisprudence. The cause of the emergence of rules regarding current Financial Technology (ius constitutum) is contained in 4 points of urgency and 3 (three) points of consideration of Bank Indonesia Regulation Number 19/12/ PBI/2017. As long as the product of Financial Technology does not conflict with the existing value system, the Financial Technology product can be developed and regulated in Indonesia in the future (ius constituendum).
\end{abstract}

Keywords: Progressivity, Financial Technology (Fintech), Business Law, Indonesia

\section{Pendahuluan}

\section{A. Latar Belakang}

Ketika dunia sedang berada dalam era digitalisasi dalam segala bentuk, Indonesia sekonyong-konyong mengikuti arus digitalisasi. Sekonyong-konyong terpesona dengan kemudahan yang ditawarkan oleh digitalisasi, lalu mengikutinya tanpa menyaring manfaat maupun kerugian yang didapat. Bahkan yang lebih mengkhawatirkan, sekonyongkonyong mengikuti tren digitalisasi

\footnotetext{
${ }^{1}$ Artikel ini didasarkan pada penelitian yang dibiayai oleh Lembaga Penelitian dan Pengabdian kepada Masyarakat (LPPM) Universitas Tarumanagara
} 
supaya dianggap bangsa yang

mengikuti peradaban.

Hal tersebut tentunya tidak diinginkan oleh semua pihak. Era digitalisasi sebagai bagian dari Revolusi Industri 4.0 merupakan era dan bukan tren. Era merupakan tahapan yang dimasuki secara sadar, bukan sekonyong-konyong menggunakan teknologi digital baru tersadar. Memasuki era digital secara sadar memerlukan tahap persiapan, karena secanggih-canggihnya teknologi, pasti memiliki sisi positif dan negatif. Memasuki era digitalisasi secara sadar, akan membuat masyarakat dapat memfungsikan teknologi secara positif, namun siap dengan dampak negatif yang dapat timbul karenanya.

Salah satu contoh munculnya tren di era digitalisasi disampaikan oleh Kementerian Komunikasi dan Informatika Republik Indonesia bahwa masyarakat tak sekedar mencari informasi atau chatting dengan

2 Kementerian Komunikasi dan Informatika, "Indonesia Akan Jadi Pemain Ekonomi Digital Terbesar di Asia Tenggara", https://www.kominfo.go.id/content/detail/644 
dikeluarkan untuk transportasi maupun komunikasi, sehingga pilihan bertransaksi digital melalui gawai banyak dipilih oleh masyarakat. Hal ini memicu perkembangan signifikan dari Teknologi Finansial (Fintech).

Di sisi lain, hukum pada umumnya belum mengatur perkembangan transaksi digital tersebut secepat seperti ketika teknologi tersebut berkembang di dalam masyarakat. Pemerintah telah mengatur beberapa peraturan tentang transaksi digital sejak satu dasawarsa yang lalu, seperti Internet Banking yang telah diatur pada tahun 2007 serta Informasi dan Transaksi Elektronik yang telah diatur sejak tahun 2008. Beberapa peraturan lainnya diterbitkan setelahnya, seperti peraturan tentang Transfer Dana pada tahun 2011, peraturan tentang Penyelenggaraan Pemrosesan Transaksi Pembayaran pada tahun 2016, dan Teknologi (Fintech) Finansial pada tahun 2017. Rangkaian sejarah pengaturan mengenai transaksi digital tersebut merupakan awal mula perkembangan penerimaan Teknologi Finansial (Fintech) dalam Hukum Bisnis di
Indonesia, baik business to business maupun business to consumer.

Rangkaian sejarah pengaturan mengenai transaksi digital menarik untuk diteliti terutama mengenai apa saja landasan pertimbangan pemerintah mengenai urgensi dari Teknologi Finansial (Fintech) sebagai pengaturan terbaru dari pemerintah, terutama mengenai pertimbangan yang melatarbelakangi urgensi munculnya Peraturan Bank Indonesia (PBI) Nomor 19/12/PBI/2017 tentang Penyelenggaraan Teknologi Finansial (Fintech). Hal yang menarik lainnya adalah untuk mengetahui sudut pandang mengenai perkembangan Teknologi Finansial (Fintech) dalam hukum bisnis yang akan datang. Hal ini dapat dilakukan dengan meneliti sudut pandang mengenai era Revolusi Industri $4.0 \quad$ yang sedang mempengaruhi segala lini, termasuk lini hukum, dan sampai batas mana, lini-lini tersebut mendukung perkembangan Finansial Teknologi pada khususnya. 
Peraturan Bank Indonesia (PBI) Nomor 19/12/PBI/2017 tentang Penyelenggaraan Teknologi Finansial (Fintech) merupakan milestone bagi perkembangan Teknologi Finansial (Fintech) di Indonesia. Hal ini tentunya baik bagi masyarakat karena dengan diaturnya Teknologi Finansial (Fintech) dalam PBI tersebut, para stakeholders khususnya penyelenggara Teknologi Finansial (Fintech) dan masyarakat memahami transaksi apa saja yang diperbolehkan dan apa urgensi dipilihnya transaksi-transaksi digital yang diperbolehkan dalam wilayah kedaulatan Republik Indonesia. Hal ini juga mengartikan bahwa pemerintah juga berperan di dalam dunia digital dari penduduknya.

\section{B. Rumusan Masalah}

1. Bagaimana progresivitas pengaturan Teknologi Finansial (Fintech) dalam Hukum Bisnis Indonesia pada saat ini (ius constitutum) menurut teori Hukum

3 Ronny Hanitjo Soemitro, Metodologi Penelitian Hukum, (Jakarta: Ghalia Indonesia, 1982), hal. 15
Progresif dari Satjipto Rahardjo dan teori Sociological Jurisprudence dari Roscoe Pound?

2. Bagaimana urgensi dan batasanbatasan penyerapan perkembangan Teknologi Finansial (Fintech) dalam Hukum Bisnis pada masa yang akan datang (ius constituendum)?

\section{Metode Penelitian}

Penelitian pada umumnya bertujuan untuk menemukan, mengembangkan atau menguji kebenaran suatu pengetahuan. Menemukan berarti berusaha memperoleh sesuatu untuk mengisi kekosongan atau kekurangan. Mengembangkan berarti memperluas dan menggali lebih dalam sesuatu yang telah ada. Menguji kebenaran dilakukan jika apa yang sudah ada diragukan kebenarannya secara ilmiah. $^{3}$ Selain itu, tujuan dari penelitian adalah untuk melakukan falsifikasi dari bentukan hukum yang 
sudah $\mathrm{ada}^{4}$, untuk menguji relevansinya dengan kebutuhan hukum masyarakat di era yang semakin berkembang (progressive).

Metode pendekatan yang digunakan dalam penelitian ini adalah yuridis normatif, dengan verifikasi terkait pengaturan tentang Teknologi Finansial (Fintech). Verifikasi dilanjutkan dengan mencari sudut pandang yang membentuk urgensi dari pengaturan yang ada sekarang (ius constitutum) maupun pengaturan yang akan datang (ius constituendum), serta melihat potensi-potensi falsifikasi untuk menguji kebenaran sudut pandang yang membentuk pengaturan Finansial Teknologi tersebut. Falsifikasi tersebut pada akhirnya akan membantu ditemukannya relevansi dengan bentukan hukum di masa yang akan datang (ius constituendum).

\footnotetext{
${ }^{4}$ Egon Guba dan Yvonna Lincoln, "Competing Paradigms in Qualitative Research", dalam N.K. Denzin dan Y. S. Lincoln (Eds), Handbook of Qualitative Research Research, (London: Sage, 1994), 114. The appropriate criteria are historical situatedness of the inquiry, the extent to which the inquiry acts to erode ignorance and misapprehensions, and the extent to which it provides a stimulus to action,
}

Selain bahan hukum primer, sekunder dan tersier sebagai bahan penelitian, digunakan pula bahan nonhukum berupa pengambilan data sekunder berupa data kualitatif maupun kuantitatif terhadap pihak-pihak terkait (Stakeholder):

1. Otoritas Jasa Keuangan (OJK)

2. Bank Indonesia (BI)

Pengolahan data melalui analisis kualitatif dilakukan untuk memperkaya sudut pandang bahkan dapat memunculkan sudut pandang baru dalam memahami ${ }^{5}$ Teknologi Finansial (Fintech) dalam hukum bisnis pada umumnya.

\section{Kerangka Teori}

Kerangka teori yang digunakan dalam penelitian ini adalah teori hukum progresif dari Satjipto Rahardjo, teori Sociological Jurisprudence dari

that is, to the transformation of the existing structure.

${ }^{5}$ Thomas A Schwandt, "Three Epistemological Stances for Qualitative Theory" dalam Norman K Denzin dan Yvonna S Lincoln (eds), Handbook of Qualitative Research (London: Sage, 2000), 191. To find meaning in an action, the inquirer must grasp the meanings that constitute in action. 


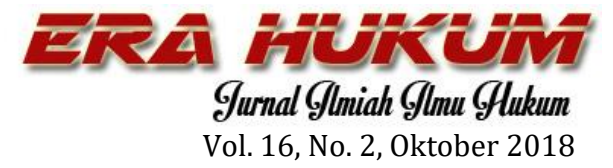

Roscoe Pound dan teori Revolusi

Industri 4.0. Teori hukum progresif dari Satjipto Rahardjo dan teori Sociological Jurisprudence dari Roscoe Pound akan digunakan dalam meneliti progresivitas Teknologi Finansial (Fintech) dalam Hukum Bisnis di Indonesia dalam hukum yang berlaku sekarang ini di Indonesia (Ius Constitutum) dan bagaimana penyesuaian kembali (readjustment) antara penyebab (cause) adanya pengaturan Teknologi Finansial (Fintech) dalam hukum bisnis dan bentuan hukum itu sendiri (rule). Sedangkan teori Revolusi Industri 4.0 akan digunakan untuk melihat kemana arah perkembangan Teknologi Finansial (Fintech) dalam Hukum Bisnis di Indonesia dalam hukum yang di masa yang akan datang di Indonesia (Ius Constituendum).

\section{Teori Hukum Progresif dari Satjipto Rahardjo}

Selanjutnya progresivitas pengaturan dalam hukum merupakan

${ }^{6}$ Shidarta, "Posisi Pemikiran Hukum Progresif Dalam Konfigurasi Aliran-Aliran Filsafat Hukum: Sebuah Diagnosis Awal", dalam tanggapan dari pemerintah untuk melayani masyarakat yang berubah dari segi cara bertransaksi bisnis. Hal ini diakomodasi dalam tulisan Satjipto Rahardjo berikut yang menjadi landasan diagnosis posisi pemikiran hukum progresif oleh Shidarta:

"Hukum progresif dan ilmu hukum progresif barangkali tidak bisa disebut sebagai suatu tipe hukum yang khas dan selesai (distinct type and a finite scheme), melainkan lebih merupakan gagasan yang mengalir, yang tidak mau terjebak dalam status quo, sehingga menjadi mandek (stagnant). Hukum progresif selalu ingin setia pada asas besar, 'hukum adalah untuk manusia.' Hukum progresif bisa diibaratkan sebagai papan petunjuk, yang selalu memperingatkan, hukum tersebut harus terus-menerus merobohkan, mengganti, membebaskan hukum yang mandek, karena tidak mampu melayani lingkungan yang berubah..."

\section{Teori Sociological Jurisprudence} dari Roscoe Pound

Dalam aliran hukum, sosiological jusprudence dari Roscoe Pound

Myrna Safitri (ed), Satjipto Rahardjo dan Hukum Progresif: Urgensi dan Kritik, (Jakarta: Epistema Institute, 2011), 54 
memberikan penjelasan mengenai bentukan hukum sebagai milestone tersebut, seperti yang diutarakannnya dalam penjelasannya mengenai pengaplikasian hukum:

"...the cause is not to be fitted to the rule but the rule to the cause."

Selain itu, ada faktor-faktor lain yang menyebabkan peraturan tersebut mengalami penyesuaian kembali (readjustment). Tekanan kepentingan sosial yang kurang diperhatikan sebelumnya, serta kebutuhan untuk merekonsiliasikannya dengan urgensi keamanan umum dan membuat kompromi baru secara terus-menerus karena perubahan yang terus-menerus dalam masyarakat. Hal ini dinyatakannya dalam:

"On the other hand, the pressure of less immediate social interests, and the need of reconciling them with the exigencies of the general security, and of making continual new compromises because of continual changes in society, has

7 Roscoe Pound, An Introduction to the Philosophy of Law, (London: Universal Law Publishing Company Pvt. Limited, 1954), 128 called ever for readjustment at least of the details of the social order. ${ }^{8}$

\section{Teori Revolusi Industri 4.0}

$$
\text { Era Revolusi Industri } 4.0
$$
merupakan era dimana kita dihadapkan dengan "fundamental technological change", seperti dikemukakan oleh Klaus Schwab, Pendiri sekaligus Ketua World Economic Forum, dalam bukunya "The Fouth Industrial Revolution" sebagai berikut:

"We live in exciting times of fundamental technological change. The pace and scope of groundbreaking scientific and technological advances coming from research facilities, start-ups and large organizations never cease to amaze me. The "science fiction" of yesterday is today becoming a reality in new products and services that won't be able to imagine having lived without." "9

\section{E. Pembahasan}

Berikut ini pembahasan mengenai Teknologi Finansial (Fintech) dalam Hukum Bisnis di Indonesia, baik

\footnotetext{
${ }^{8}$ Loc. Cit.

9 Klaus Schwab, The Fourth Industrial Revolution, (London: Penguin, 2017), vii
} 
business to business maupun business to consumer. Pembahasan ini dilakukan dalam konteks ius constitutum dan ius constituendum.

\section{Teknologi Finansial (Fintech) Dalam Hukum Bisnis Secara Umum}

Secara umum teknologi finansial (Fintech) memiliki peran yang cukup penting dalam memperlancar transaksi bisnis. Teknologi Finansial (Fintech) memiliki cakupan yang cukup luas, mencakup sistem transaksi gabungan antara sistem keuangan dan teknologi keuangan. Sistem transaksi gabungan dalam Teknologi Finansial (Fintech) tersebut menunjang transaksi bisnis terkait dengan produk-produk keuangan, serta proses penjualan dan pembelian. Menurut Roy S. Freedman dalam bukunya Introduction to Financial Technology, batasan Teknologi Finansial (Fintech) secara umum adalah sebagai berikut:

"Financial technology is concerned with building systems that model, value, and process financial products such as bonds, stocks, contracts, and money. At a minimum, financial products are represented by the dimensions of price, time and credit. Like commercial systems, financial systems incorporate trading systems and trading technology to enable the buying and selling products at different times and in different market spaces. This includes the simultaneous buying and selling of the same product in different markets, at the same time." 10

Dalam terjemahan bebasnya, teknologi keuangan berkaitan dengan membangun sistem yang memodelkan, menghargai, dan memproses produk keuangan seperti obligasi, saham, kontrak, dan uang. Minimal, produk keuangan diwakili oleh dimensi harga, waktu dan kredit. Seperti sistem komersial, sistem keuangan menggabungkan sistem perdagangan dan teknologi perdagangan untuk memungkinkan pembelian dan penjualan produk pada waktu yang berbeda dan di ruang pasar yang berbeda. Ini termasuk pembelian dan penjualan secara bersamaan dari

${ }^{10}$ Roy S. Freedman, Introduction to Financial Technology, (London: Elsevier Inc., 2006), 1 
produk yang sama di pasar yang berbeda, pada saat yang sama.

Oleh karena itu, sistem dan produk Teknologi Finansial (Fintech) erat hubungan dengan dunia bisnis. Hanya saja, batasan tersebut tidak dimiliki oleh semua negara. Ada yang memberikan batasan lebih luas, ada pula yang memberikan batasan lebih sempit.

Selain itu, perlu pula diperhatikan aspek teknologi yang terkandung dalam Teknologi Finansial (Fintech) yaitu:

"Financial technology depends on standard secure communication protocols for initiating and synchronizing communication, for authenticating market participants, and for ensuring that the market participants can communicate quickly in a common language. This enables the fast delivery of information, orders, and news on public or private, physical or nonphysical communication networks." 11

Terjemahan bebasnya yaitu teknologi keuangan bergantung pada protokol komunikasi aman standar

${ }^{11}$ Loc. Cit. untuk memulai dan sinkronisasi komunikasi, untuk mengautentikasi peserta pasar, dan untuk memastikan bahwa pelaku pasar dapat berkomunikasi dengan cepat dalam bahasa yang sama. Ini memungkinkan pengiriman informasi, pesanan, dan berita yang cepat pada jaringan komunikasi publik atau pribadi, baik secara fisik maupun non-fisik.

Selain itu dikatakan pula bahwa:

"Financial technology integrates mathematical, statistical, computing, and economic model with news and analytical systems, these are further integrated with message, transaction, order processing, and payment systems. Financial systems perform their activities in compliance with rules, procedures, guidelines, and regulations. Like military systems, financial systems are involved with strategy and tactics, logistic, information, processing, secrecy, and resource allocation." 12

Terjemahan bebasnya yaitu teknologi keuangan mengintegrasikan model matematika, statistik, komputasi, dan ekonomi dengan sistem berita dan analisis, ini lebih terintegrasi

${ }^{12}$ Loc. Cit. 
dengan pesan, transaksi, pemrosesan pemesanan, dan sistem pembayaran. Sistem keuangan melakukan aktivitasnya sesuai dengan aturan, prosedur, pedoman, dan peraturan. Seperti sistem militer, sistem keuangan melibatkan strategi dan taktik, logistik, informasi, pemrosesan, kerahasiaan, dan alokasi sumber daya.

Sehingga dapat disimpulkan bahwa Teknologi Finansial (Fintech) dalam Hukum Bisnis, baik business to business maupun business to consumer, merupakan kajian yang sifatnya multidisipliner transaksi bisnis yang dilakukan bersangkutan dengan pelaksanaannya yang secara teknis terintegrasi dengan teknologi.

Aspek yang terkait erat dengan Hukum Bisnis, baik business to business maupun business to consumer, dalam Teknologi Finansial (Fintech) adalah aspek transaksi bisnis. Transaksi bisnis baik business to business maupun business to consumer yang diawali dengan adanya perjanjian

\footnotetext{
${ }^{13}$ Catherine Elliot dan Frances Quinn, Contract Law, (Edinburgh: Pearson Education, 2009), 12
}

secara elektronik dalam Teknologi Finansial (Fintech) pada prinsipnya sama dengan transaksi bisnis yang dilakukan dalam dunia konvensial dimana pada salah satu sisi terdapat penawaran (offer) dan disisi lain terdapat penerimaan (acceptance).

Beberapa komunikasi yang ditawarkan melalui Teknologi Finansial (Fintech) dapat dikategorikan sebagai penawaran apabila terdapat indikasi dari pemberi tawaran (offeror) mengenai adanya penawaran kontrak dan adanya kemauan dari pemberi tawaran (offeror) tersebut untuk terikat oleh kontrak tersebut apabila penawaran (offer) tersebut diterima oleh penerima tawaran (offeree), seperti yang didefinisikan di bawah ini $^{13}$ :

\footnotetext{
"A communication will be treated as an offer if it indicates the terms on which the offeror is prepared to make a contract (such a price of the goods for sale) and gives a clear indication that the offeror intends to be bound by those terms if they are accepted by the offeree."
} 
Penawaran tersebut dalam Teknologi Finansial (Fintech) dapat diterima dengan melakukan klik pada tombol $O K$ atau submit, setelah terlebih dahulu menyetujui syarat dan ketentuan yang berlaku. Transanksi bisnis yang dilakukan dalam Teknologi Finansial (Fintech) tersebut juga meliputi transaksi bisnis pada umumnya karena dalam Teknologi Finansial (Fintech), pihak-pihak berniat untuk terikat secara hukum, seperti yang tercantum dalam definisi berikut $^{14}$ :

"There is a strong presumption in commercial agreements that the parties intend to be legally bound, and unless there is very clear contrary evidence, this presumption will not be rebutted."

Selain itu, di negara-negara Eropa Kontinental dan Anglo Saxon terdapat pula peraturan yang membatasi substansi kontrak agar kontrak hanya dilakukan dalam ranah yang sah.

${ }^{14}$ Ibid. hal. 62

${ }^{15}$ Pasal 1 angka 1 PBI Nomor 19/12/PBI/2017
2. Definisi Teknologi Finansial (Fintech) Dalam Hukum Bisnis di Indonesia (Ius Constitutum)

Dalam konteks Ius Constitutum atau hukum nasional Republik Indonesia yang berlaku pada masa sekarang ini, Teknologi Finansial (Fintech) telah diatur dalam Peraturan Bank Indonesia (PBI) Nomor 19/12/PBI/2017 tentang Penyelenggaraan Teknologi Finansial (Fintech). Dalam PBI tersebut Teknologi Finansial (Fintech) didefinisikan sebagai:

"penggunaan teknologi dalam sistem keuangan yang menghasilkan produk, layanan, teknologi, dan/atau model bisnis baru serta dapat berdampak pada stabilitas monoter, stabilitas sistem keuangan, dan/atau efisiensi, kelancaran, keamanan, dan keandalan sistem pembayaran."15

Penyelenggaraan Teknologi Finansial (Fintech) dalam PBI ini dikategorikan ke dalam beberapa kriteria $^{16}$ dan setiap kriteria tersebut telah diberikan batasan yang jelas berupa contoh-contoh riil yang dapat

${ }^{16}$ Pasal 3 ayat (1) PBI Nomor 19/12/PBI/2017 
ditemukan dalam Penjelasan PBI

Nomor 19/12/PBI/2017 tersebut:

\section{a. Sistem pembayaran}

Sistem pembayaran mencakup otorisasi, kliring, penyelesaian akhir, dan pelaksanaan pembayaran. Contoh: penyelenggaran Teknologi Finansial (Fintech) pada kategori sistem pembayaran antara lain penggunaan teknologi blockchain atau distributed ledger untuk penyelenggaraan transfer dana, uang elektronik, dompet elektronik, dan mobile payments. ${ }^{17}$

\section{b. Pendukung pasar \\ Yang dimaksud dengan "pendukung pasar" adalah} Teknologi Finansial (Fintech) yang menggunakan teknologi informasi dan/atau teknologi elektronik atau memfasilitasi pemberian informasi yang lebih cepat dan lebih murah terkait dengan produk dan/atau layanan jasa keuangan kepada masyarakat.

Contoh: penyelenggaraan

Teknologi

Finansial (Fintech) pada kategori pendukung pasar (market support), antara lain penyediaan data perbandingan informasi produk atau layanan jasa keuangan. ${ }^{18}$

\section{c. Manajemen investasi dan manajemen risiko}

Penyelenggaraan Teknologi

Finansial (Fintech) pada kategori manajemen investasi dan

17 Penjelasan Pasal 3 ayat (1) huruf (a) PBI Nomor 19/12/PBI/2017

${ }^{18}$ Loc. Cit.

${ }^{19}$ Loc. Cit. manajemen risiko antara lain penyediaan produk investasi online dan asuransi online. ${ }^{19}$

\section{d. Pinjaman, pembiayaan, dan penyediaan modal \\ Penyelenggaraan Teknologi}

Finansial (Fintech) pada kategori ini termasuk pinjaman (lending), pembiayaan (financing atau funding), dan penyediaan modal (capital raising) antara lain layanan pinjam meminjam uang berbasis teknologi informasi (peer-to-peer lending) serta pembiayaan atau penggalangan dana berbasis teknologi informasi (crowdfunding). ${ }^{20}$

\section{e. Jasa finansial lainnya}

Yang dimaksud dengan "jasa finansial lainnya" adalah Teknologi Finansial (Fintech) selain kategori sistem pembayaran, pendukung pasar, manajemen investasi dan manajemen risiko, serta pinjaman, pembiayaan, dan penyediaan modal. ${ }^{21}$

Teknologi Finansial (Fintech) sebagaimana dimaksud di atas memiliki kriteria ${ }^{22}$ :

a. Bersifat inovatif;

b. Dapat berdampak pada produk, layanan, teknologi, dan/atau

${ }^{20}$ Loc. Cit.

${ }^{21}$ Loc. Cit.

${ }^{22}$ Pasal 3 ayat (2) PBI Nomor 19/12/PBI/2017 
model bisnis finansial yang telah eksis;

c. Dapat memberikan manfaat bagi masyarakat;

d. Dapat digunakan secara luas; dan

e. Kriteria lain yang ditetapkan oleh Bank Indonesia.

Dari definisi Teknologi

Finansial (Fintech) tersebut di atas terlihat bahwa PBI Nomor 19/12/PBI/2017 telah

mendefinisikan secara jelas pengaplikasian Teknologi dalam Hukum Bisnis Indonesia baik business to business maupun business to consumer dalam terang kemajuan teknologi. Namun demikian pengembangan Teknologi Finansial (Fintech) secara utuh belum banyak terdapat di Indonesia, sehingga pengertian Teknologi Finansial (Fintech) tersebut dapat mengerucut produk Teknologi Finansial (Fintech) yang sudah banyak digunakan di Indonesia yaitu uang elektronik yang pengaturan juga terdapat dalam Peraturan Bank Indonesia Nomor 18/40/PBI/2016 tentang Penyelenggaraan Pemrosesan Transaksi Pembayaran,
Surat Edaran Bank Indonesia Nomor 18/22/DKSP perihal Penyelenggaraan Layanan Keuangan Elektronik dan Peraturan Bank Indonesia Nomor 18/17/PBI/2016 tentang Uang Elektronik.

Transaksi bisnis yang dilakukan di Indonesia tentu saja harus memenuhi ketentuan umum mengenai perjanjian yang terdapat pada Pasal 1313 dan Pasal 1338 Kitab Undang-Undang Hukum Perdata (selanjutnya disebut sebagai KUHPer) serta syarat sah dalam Pasal 1320 Kitab Undang-Undang Hukum Perdata. Para pihak dapat melakukan perjanjian dengan menggunakan asas kebebasan berkontrak, artinya hukum perjanjian memberi kebebasan yang seluas-luasnya kepada para pihak untuk mengadakan perjanjian yang berisi apa saja, dengan syarat atau sepanjang perjanjian tersebut tidak melanggar undang-undang, ketertiban umum dan kesusilaan. Hal ini disebutkan secara tegas dalam Pasal 1337 KUHPer: 
"Suatu sebab adalah terlarang, jika sebab itu dilarang oleh undang-undang atau bila sebab itu bertentangan dengan kesusilaan atau dengan ketertiban umum."

Selain itu, semua perjanjian harus dibuat dengan itikad baik, sebagaimana disebutkan dalam Pasal 1338 (3) KUH Perdata.

\section{Progresivitas Teknologi Finansial (Fintech) Kini (Ius Constitutum) di Indonesia}

Progresivitas Teknologi Finansial dalam masyarakat dari segi manfaat yang diterima oleh masyarakat merupakan faktor utama yang menyebabkan pengaturan mengenai Teknologi Finansial diadopsi dalam PBI Nomor 19/12/PBI/2017. Manfaat tersebut contohnya dengan adanya sistem tracking yang jelas dan mudah diakses pada Teknologi Finansial (Fintech) secara umum.

Progresivitas pengaturan Teknologi Finansial (Fintech) tersebut dimulai dengan adanya dasar tentang aspek pembuktian secara elektronik. Menurut Pasal 5 ayat (1) UndangUndang Nomor 11 Tahun 2008 tentang
Informasi dan Transaksi Elektronik sebagaimana diubah dengan UndangUndang Nomor 19 Tahun 2016 yang mengatur mengenai hal yang sama (selanjutnya disebut sebagai UU ITE). Bukti elektronik merupakan salah satu alat bukti hukum yang sah dalam Hukum Bisnis, baik business to business maupun business to consumer Indonesia:

\section{"Informasi elektronik dan/atau dokumen elektronik dan/atau hasil cetaknya merupakan alat bukti hukum yang sah."}

Diterimanya bukti elektronik sebagai salah satu alat bukti yang sah di pengadilan 10 tahun lalu telah menjadi landasan Teknologi Finansial (Fintech) dalam dunia Hukum Bisnis, baik business to business maupun business to consumer. Hal ini juga diperkuat dengan diperluasnya Hukum Acara Perdata dengan adanya pembuktian elektronik tersebut, sebagaimana tertulis dalam Pasal 5 ayat (2) UU ITE tersebut:

"Informasi elektronik dan/atau dokumen elektronik dan/atau hasil cetaknya sebagaimana dimaksud pada ayat (1) merupakan perluasan dari alat bukti yang sah 
sesuai dengan Hukum Acara yang berlaku di Indonesia."

Perluasan dalam Hukum Acara tersebut merupakan salah satu hal yang memperkuat perlindungan dalam pembuktian dokumen elektronik di pengadilan dalam sengketa Teknologi Finansial (Fintech) di dalam Hukum Bisnis di Indonesia, baik business to business maupun business to consumer.

Salah satu pemicu diterimanya bukti elektronik sebagai salah satu alat bukti yang sah tidak lepas dari penerimaan internet banking dalam masyarakat dan diaturnya internet banking tersebut setahun sebelumnya dalam Surat Edaran Bank Indonesia No. 16/18/DPNP tentang Penerapan Manajemen Risiko pada Aktivitas Pelayanan Jasa Bank Melalui Internet Banking. Dalam tiga tahapan yang dapat dilakukan oleh nasabah melalui internet banking yaitu Informational Internet Banking, Communicative Internet Banking dan Transactional Internet Banking, masyarakat telah mengenai transaksi elektronik dengan rentang batas tanggung jawab masingmasing.

Setelah 10 tahun berselang sejak internet banking tersebut diatur dalam Surat Edaran Bank Indonesia, terdapat beberapa pengaturan mengenai Teknologi Finansial (Fintech) yang telah diatur. Pengaturan oleh pemerintah tersebut menggambarkan bahwa pemerintah menerima Teknologi Finansial (Fintech) dalam sistem hukum Indonesia terutama dalam PBI Nomor 19/12/PBI/2017 tentang Penyelenggaraan Teknologi Finansial (Fintech).

Jika dilihat dari review pengaturan mengenai transaksi elektronik, maka terdapat progresivitas pengaturan Teknologi Finansial (Fintech) dalam peraturan perundang-undangan di Indonesia. Hal yang menarik dari progresivitas tersebut adalah mengenai bagaimana pergeseran paradigma mengenai keterhubungan antara Hukum Bisnis, baik business to business maupun business to consumer, dan teknologi tersebut dapat terjadi dalam pertimbangan latar berlakang diakomodasinya Teknologi 
Finansial (Fintech) oleh pembentuk kebijakan dari tahun ke tahun. Melalui hal tersebut kita dapat melihat peran Teknologi Finansial (Fintech) sebagai bagian dari teknologi informasi dalam Hukum Bisnis, baik business to business maupun business to consumer.

Progresivitas

mengenai Teknologi Finansial

(Fintech) di Indonesia menjawab kebutuhan masyarakat akan hukum Teknologi Finansial (Fintech) tersebut. Seperti yang diutarakan oleh Satjipto Raharjo, pakar hukum progresif Indonesia bahwa "hukum adalah untuk rakyat" ${ }^{\prime 23}$ maka sewajarnyalah pengaturan mengenai Teknologi Finansial (Fintech) dalam Hukum Bisnis di Indonesia, baik business to business maupun business to consumer, menjawab kebutuhan masyarakat akan kepastian hukum Teknologi Finansial (Fintech).
Selanjutnya

progresivitas

pengaturan mengenai Teknologi Finansial (Fintech) dalam Hukum Bisnis, baik business to business maupun business to consumer, merupakan tanggapan dari pemerintah untuk melayani masyarakat yang berubah dari segi cara bertransaksi bisnis. Hal ini diakomodasi dalam tulisan Satjipto Rahardjo berikut yang menjadi landasan diagnosis posisi pemikiran hukum progresif oleh Shidarta:

"Hukum progresif dan ilmu hukum progresif barangkali tidak bisa disebut sebagai suatu tipe hukum yang khas dan selesai (distinct type and a finite scheme), melainkan lebih merupakan gagasan yang mengalir, yang tidak mau terjebak dalam status quo, sehingga menjadi mandek (stagnant). Hukum progresif selalu ingin setia pada asas besar, 'hukum adalah untuk manusia.' Hukum progresif bisa diibaratkan sebagai papan petunjuk, yang selalu memperingatkan, hukum tersebut harus terus-menerus merobohkan,

pengadilan. Namun dalam hal pembicaraan mengenai untuk siapa hukum itu ada, maka hukum progresif dapat pula mengakomodasi pengaturan Teknologi Finansial dalam Hukum Bisnis Indonesia. 
mengganti, membebaskan hukum yang mandek, karena tidak mampu melayani lingkungan yang berubah..."24

Perkembangan teknologi merupakan bagian dari 'lingkungan yang berubah'. Cara bertransaksi bisnis diharapkan mampu menanggapi perubahan dalam hal perkembangan teknologi tersebut. Dalam menanggapi perkembangan teknologi tersebut, ada beberapa terobosan teknologi yang diterima oleh pemerintah sebagai terobosan cara bertransaksi bisnis, ada pula yang tidak diterima. Penerimaan oleh pemerintah tersebut pada gilirannya dinyatakan dalam bentuk diaturnya terobosan cara bertransaksi bisnis tersebut dalam peraturan perundang-undangan. Dengan adanya pengaturan tersebut, bukan berarti progresivitas tersebut telah selesai. Tetapi pada titik waktu tertentu, harus ada bentukan hukum sebagai milestone perjalanan dari progresivitas itu sendiri.

Berkaitan dengan progresivitas tersebut Bank Indonesia memiliki pertimbangan dalam melakukan pengaturan terhadap Penyelenggaraan Teknologi Finansial (Fintech) dalam PBI Nomor 19/12/PBI/2017. Adapun pertimbangan tersebut adalah sebagai berikut:

a. Bahwa perkembangan teknologi dan sistem informasi terus melahirkan berbagai inovasi, khususnya yang berkaitan dngan teknologi finansial untuk memenuhi berbagai kebutuhan masyarakat termasuk akses terhadap layanan finansial dan pemrosesan transaksi;

b. Bahwa perkembangan teknologi finansial di satu sisi terbukti membawa manfaat bagi konsumen, pelaku usaha maupun perekonomian nasional, namun di sisi lain memiliki potensi risiko yang apabila tidak dimitigasi secara baik dapat mengganggu sistem keuangan;

c. Bahwa ekosistem teknologi finansial perlu terus dimonitor dan dikembangkan untuk mendukung terciptanya stabilitas moneter, stabilitas sitem keuangan, serta system pembayaran yang efisien, lancar, aman, dan andal untuk mendukung pertumbuhan ekonomi nasional yang berkelanjutan dan inklusif;

d. Bahwa penyelenggaraan teknologi finansial harus menerapkan prinsip perlindungan konsumen serta manajemen risiko dan kehati-

${ }^{24}$ Shidarta, Ibid., 54 
hatian dengan tetap memperhatikan perluasan akses, kepentingan nasional, serta standar dan praktik internasional yang berlaku;

e. Bahwa respons kebijakan Bank Indonesia terhadap perkembangan teknologi finansial harus tetap sinkron, harmonis, dan terintegrasi dengan kebijakan Bank Indonesia lainnya seperti penyelenggaraan pemrosesan transaksi pembayaran dan gerbang pembayaran nasional (national payment gateway) serta perlu dikoordinasikan dengan otoritas terkait;

Selanjutnya urgensi pengaturan

Teknologi Finansial (Fintech) dalam

PBI Nomor 19/12/PBI/2017 tersebut adalah sebagai berikut ${ }^{25}$ :

"Inovasi teknologi dan penetrasinya dengan fitur finansial terus berlangsung dan menandai munculnya momentum transformasi di dunia finansial. Era digitalisasi ekonomi memicu penggunaan teknologi internet, telepon pintar, dan big data hingga ke level konsumen akhir secara lebih efisien, baik dari segi waktu, akses, maupun biaya. Dalam konteks tersebut, arus digitalisasi ekonomi termasuk di dalamnya Teknologi Finansial memiliki potensi yang besar untuk mendorong alokasi sumber daya ekonomi secara lebih efisien dan pada gilirannya mendorong peningkatan produktivitas serta memberikan manfaat yang lebih besar bagi masyarakat.

Di sisi lain, peleburan inovasi teknologi dengan fitur finansial juga membawa risiko tersendiri. Fungsi konvensional cenderung tereduksi perannya bahkan seringkali tergusur oleh fungsi baru yang diperkenalkan oleh inovasi teknologi yang cenderung bersifat mengganggu (disruptive). Pemain baru bermunculan karena berkurangnya halangan untuk masuk (barriers to entry) di industri keuangan. Pemain baru ini umumnya menjangkau segmen masyarakat dan/atau dunia usaha yang rata-rata tidak atau belum tersebut oleh sektor keuangan formal, baik yang disebabkan oleh keterbatasan kapasitas jangkauan sektor keuangan formal maupun belum atau tidak memenuhi kriteria manajemen risiko yang dipersyaratkan secara baku oleh sektor keuangan formal.

Sehubungan dengan hal tersebut di atas, guna pelaksanaan tugas menetapkan dan melaksanakan kebijakan di bidang moneter, menetapkan dan melaksanakan kebijakan di bidang stabilitas sistem keuangan termasuk makroprudensial, serta menerapkan dan melaksanakan kebijakan di bidang sistem pembayaran, Bank Indonesia perlu menetapkan pengaturan, pengawasan, dan pemantauan

${ }^{25}$ Penjelasan PBI Nomor 19/12/PBI/2017 


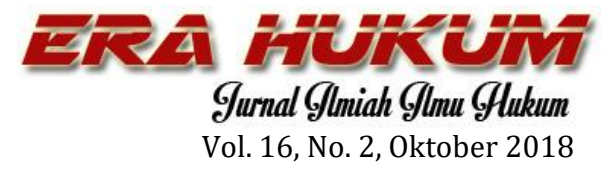

terhadap penyelenggaraan Teknologi Finansial. Pengaturan, pengawasan, dan pemantauan ini penting agar penyelenggaraan Teknologi Finansial dimonitor dan diarahkan dengan baik sehingga manfaat dari Teknologi Finansial dapat lebih dinikmati oleh masyaraakt dan berbagai risiko termasuk potensi muncul dan berkembangnya transaksi perekonomian yang tidak terawasi (shadow economy) dapat termitigasi dengan baik. Selain itu, pengaturan dan pengawasan ini penting untuk terus mendorong pengembangan ekosistem Teknologi Finansial agar semakin dapat dirasakan manfaatnya oleh masyarakat. Seiring dengan semakin diadopsinya Teknologi Finansial oleh masyarakat, menjadi krusial bagi Bank Indonesia untuk mewajibkan penyelenggara Teknologi Finansial tetap menerapkan prinsip perlindungan konsumen serta manajemen risiko dan kehatihatian."

Dari urgensi dalam PBI Nomor 19/12/PBI/2017 tersebut dapat disimpulkan 4 (empat) hal yang menjadi urgensi Teknologi Financial (Fintech) secara spesifik: a. Mendorong alokasi sumber daya ekonomi secara lebih efisien;

b. Mendorong peningkatan produktivitas serta memberikan manfaat yang lebih besar bagi masyarakat melalui digitalisasi ekonomi;

c. Sebagai konsekuensi dari semakin diadopsinya Teknologi Finansial oleh masyarakat;

d. Memitigasi berkembangnya transaksi perekonomian yang tidak terawasi (shadow economy).

Pertimbangan dan urgensi tersebut dimuat dalam tujuan dan ruang lingkup yaitu $^{26}$ :

"Bank Indonesia mengatur penyelenggaraan Teknologi Finansial untuk mendorong inovasi di bidang keuangan dengan menerapkan prinsip perlindungan konsumen serta manajemen risiko dan kehati-hatian guna tetap menjaga stabilitas moneter, stabilitas sistem keuangan, dan sistem pembayaran yang efisien, lancar, aman, dan andal."

${ }^{26}$ Pasal 2 PBI Nomor 19/12/PBI/2017 
Pertimbangan maupun urgensi dari Bank Indonesia tersebut jika dikaitkan dengan sosiological jusprudence dari Roscoe Pound memberikan penjelasan mengenai bentukan hukum sebagai milestone tersebut, seperti yang diutarakannnya dalam penjelasannya mengenai pengaplikasian hukum:

"...the cause is not to be fitted to the rule but the rule to the cause" $^{27}$

Penyebab (cause) dari munculnya peraturan (rule) mengenai Teknologi Finansial (Fintech) tersebut tertuang dalam 3 (tiga) poin awal dari pertimbangan atas Peraturan Bank Indonesia Nomor 19/12/PBI 2017 tersebut di atas, yaitu:

a. Bahwa perkembangan teknologi dan sistem informasi terus melahirkan berbagai inovasi, khususnya yang berkaitan dengan teknologi finansial untuk memenuhi berbagai kebutuhan masyarakat termasuk akses terhadap layanan finansial dan pemrosesan transaksi;

b. Bahwa perkembangan teknologi finansial di satu sisi terbukti membawa manfaat bagi konsumen, pelaku usaha maupun perekonomian nasional, namun di sisi lain memiliki potensi risiko yang apabila tidak dimitigasi secara baik dapat mengganggu sistem keuangan;

c. Bahwa ekosistem teknologi finansial perlu terus dimonitor dan dikembangkan untuk mendukung terciptanya stabilitas moneter, stabilitas sistem keuangan, serta sistem pembayaran yang efisien, lancar, aman, dan andal untuk mendukung pertumbuhan ekonomi nasional yang berkelanjutan dan inklusif.

Dalam ketiga poin tersebut terdapat penyebab (cause) dari munculnya peraturan (rule) mengenai Teknologi Finansial (Fintech) tersebut. Penyebab (cause) tersebut muncul untuk menjawab kebutuhan dari

${ }^{27}$ Roscoe Pound, Op. Cit., 128 
masyarakat, pemerintah dan pertumbuhan ekonomi nasional yang terkait dengan Teknologi Finansial (Fintech) itu sendiri. Dari pihak masyarakat terdapat kebutuhan akan akses terhadap layanan finansial dan pemrosesan transaksi. Dari pihak pemerintah, dalam hal ini Bank Indonensia terdapat kepentingan mitigasi risiko agar perkembangan Teknologi Finansial (Fintech) tidak mengganggu sistem keuangan. Selanjutnya, terkait dengan pertumbuhan ekonomi nasional, Teknologi Finansial (Fintech) perlu terus dimonitor dan dikembangkan.

Ketiga hal ini yang selanjutnya menciptakan peraturan (rule) terkait Teknologi Finansial (Fintech) seperti Peraturan Bank Indonesia Nomor 18/40/PBI/2016 tentang Penyelenggaraan Pemrosesan Transaksi Pembayaran, Surat Edaran Bank Indonesia Nomor 18/22/DKSP perihal Penyelenggaraan Layanan Keuangan Elektronik, Peraturan Bank Indonesia Nomor 18/17/PBI/2016 tentang Uang Elektronik dan yang paling terkait dengan Teknologi Finansial (Fintech) yaitu Peraturan Bank Indonesia Nomor 19/12/PBI/2017 tentang Penyelenggaraan Teknologi Finansial (Fintech).

Peraturan (rule) disebut oleh Roscoe Pound sebagai landasan tetap (fixed basis) yang melindungi kepentingan sosial terpenting dalam keamanan umum (the paramount social interest in the general security). Hal ini disebutkannya dalam pembahasan mengenai fungsi dari filosofi hukum berikut:

"Two needs have determined philosophical thinking about law. On the one hand, the paramount social interest in the general security, which has an interest in peace and order dictated the very beginnings of law, has led men to seek some fixed basis of a certain ordering of human action which should restrain magisterial as well as individual wilfulness and assure a firm and stable social order. ${ }^{28}$

${ }^{28}$ Ibid., 18 
Ketiga poin tersebut menjadi landasan tetap (fixed basis) dari peraturan mengenai Teknologi

Finansial (Fintech) tersebut diatas terutama PBI Nomor 19/12/PBI/2017. Hal inilah yang menyebabkan hasil analisis progresif mengenai kebutuhan masyarakat akan finansial teknologi tersebut dibentuk (figuring out) dalam bentuk peraturan (rule).

Selain itu, ada faktor-faktor lain yang menyebabkan peraturan tersebut mengalami penyesuaian kembali (readjustment) dalam urgensi pengaturan Teknologi Finansial (Fintech) dalam Penjelasan PBI Nomor 19/12/PBI/2017 tersebut di atas:

$\begin{array}{lr}\text { "Seiring dengan } & \text { semakin } \\ \text { diadopsinya } & \text { Teknologi Finansial } \\ \text { oleh masyarakat, menjadi krusial } \\ \text { bagi Bank } & \text { Indonesia untuk } \\ \text { mewajibkan } & \text { penyelenggara } \\ \text { Teknologi Finansial tetap } \\ \text { menerapkan prinsip perlindungan } \\ \text { konsumen serta manajemen risiko } \\ \text { dan kehati-hatian." }\end{array}$

Faktor pertama adalah penyesuaian kembali (readjustment) tekanan kepentingan sosial yang kurang diperhatikan sebelumnya, serta kebutuhan untuk merekonsiliasikannya dengan urgensi keamanan umum dan membuat kompromi baru yaitu diadopsinya Teknologi Finansial (Fintech) oleh masyarakat. Perubahan dalam masyarakat ini dinyatakan oleh Roscoe Pound dalam:

"On the other hand, the pressure of less immediate social interests, and the need of reconciling them with the exigencies of the general security, and of making continual new compromises because of continual changes in society, has called ever for readjustment at least of the details of the social order. ${ }^{29}$

Penyesuaian kembali (readjustment) penyelenggaraan transaksi bisnis dengan progresivitas Teknologi Finansial (Fintech) sebenarnya tidak mengubah syarat sah perjanjian yang tercantum dalam peraturan perundang-undangan Indonesia, hanya saja cara penyelenggaraan transaksi yang berubah. Sebelumnya konvensional menjadi elektronik dan selanjutnya

${ }^{29}$ Loc. Cit. 


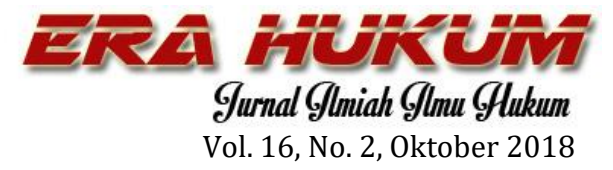

berkembang menjadi uang elektronik, dompet elektronik dan Teknologi Finansial (Fintech) lainnya.

Penyesuaian kembali penyelenggaraan transaksi bisnis dengan progresivitas Teknologi Finansial (Fintech) sebenarnya tidak mengubah syarat sah perjanjian yang tercantum dalam peraturan perundangundangan Indonesia, hanya saja cara penyelenggaraan transaksi yang berubah. Sebelumnya konvensional menjadi elektronik dan selanjutnya berkembang menjadi uang elektronik, dompet elektronik dan Teknologi Finansial (Fintech).

Faktor kedua adalah perubahan cara bertransaksi dari sistem konvensional menjadi elektronik dalam progresivitas Teknologi Finansial (Fintech) digolongkan ke dalam Hukum Bisnis, baik business to business maupun business to

\footnotetext{
${ }^{30}$ Vasant Dhar dan Roger Stein, "FinTech Platforms and Strategy: Integrating Trust and Automation in Finance", Communications of the ACM, Vol. 60 Issue 10 Tahun 2017, 33. Lihat juga William Magnuson, "Regulating Fintech", Vanderbilt Law Review, Vol. 71 Issue 4, Tahun 2018. See also George Walker, "Financial Technology Law: A New Beginning
}

consumer, terutama penggunaan platform teknologi untuk kepentingan bisnis, seperti dalam tulisan berikut:
"Platform as an entity that provides a nexus of operational and business rules; integrated technology and architecture and engines; and channel access that facilitates exchange between two or more interdependent groups, usually consumers and producers. Internet platforms always have three essential components:

i. They are "open," allowing easy participations;

ii. They implement key business and operational processes, some of which typically exhibit network effects that increase in value as participation increases;

iii. They implement these business processes automatically using enabling technology (which may also capture and generate vast amounts of data that enhances the value of the platform $)^{30}$

Dari tulisan tersebut dapat diketahui kemudahan-kemudahan pelaksanaan bisnis yang dilaksanakan

and A New Future", GPSolo, Vol. 34 Issue 3, Tahun 2017. Lihat juga Rory Van Loo, "Making Innovation More Competitive", UCLA Law Review, Vol. 65 Issue 1 Tahun 2018. Lihat juga David Varga, "FinTech, The New Era of Financial Services", Budapest Management Review, Vol. 48 Issue 11, Tahun 2017. 
melalui platform teknologi terutama kemudahan berpartisipasi, kemudahan operasional serta kemudahan pengelolaan data. Kemudahankemudahan tersebut telah diserap oleh Teknologi Finansial (Fintech) di Indonesia dalam memberikan manfaat bagi masyarakat.

Selanjutnya tulisan mengenai bagaimana mengakomodasi faktor model bisnis inovatif, teknologi modern dan perdagangan berikut ini ${ }^{31}$ :

"The sheer number of internet and mobile payment options and speed of adoption highlights the conundrum: how can any legal and regulatory regime possibly keep up with the pace of technological advances and adoption? Internet and mobile payment methods have revolutionized modern commerce, but the law understandably lags behind. As a component part of establishing a comprehensive and consistent regulatory regime for new and merging payment systems, this article suggests that existing law, such as state money transmitter laws, must be reexamined in light of technological advances and charges in consumer behaviour to clearly define the scope of their applicability to new business model."

Ketiga faktor tersebut telah teraplikasi dalam PBI Nomor 19/12/PBI/2017 terutama dalam definisi Teknologi Finansial (Fintech) dan pengaturan mengenai Regulatory Sandbox yang akan dijelaskan dalam sub selanjutnya. Hal ini menandakan bahwa PBI Nomor 19/12/PBI/2017 telah mendefinisikan secara jelas pengaplikasian Teknologi dalam Hukum Bisnis Indonesia, baik business to business maupun business to consumer, terutama dalam terang kemajuan teknologi.

\section{Pelaksanaan} Teknologi Finansial (Fintech) di Indonesia

Berdasarkan penelitian yang dilakukan, selain adanya urgensi dan pengaturan termasuk di dalamnya definisi mengenai Teknologi Finansial (Fintech) dalam Hukum Bisnis di Indonesia, baik business to business

${ }^{31}$ Kevin V. Tu, "Regulating the New Cashless World", Alabama Law Review, Vol. 65 Issue 1, Tahun 2013, 82 
maupun business to consumer, Bank Indonesia telah menyusun sistem pengujian penyelenggaraan Teknologi Finansial (Fintech) dengan sistem Regulatory Sandbox. Pengujian terhadap penyelenggara Teknologi Finansial (Fintech) yang telah mendaftarkan dirinya dilakukan oleh penyelenggara Regulatory Sandbox. Berdasarkan penelitian yang dilakukan terdapat data sekunder mengenai jumlah penyelenggara Regulatory Sandbox dan jumlah Penyelenggara Teknologi Finansial (Fintech) yang lulus uji Regulatory Sandbox. Dalam PBI Nomor 19/12/PBI/2017 dijelaskan mengenai kewajiban melakukan pendaftaran pada Bank Indonesia ${ }^{32}$ bagi penyelenggaran Teknologi Finansial (Fintech) yang akan atau telah melakukan kegiatan yang memenuhi kriteria Pasal 3 ayat (2) PBI Nomor 19/12/PBI/2017:

Kewajiban pendaftaran tersebut dikecualikan bagi penyelenggara jasa sistem pembayaran yang telah memperoleh izin dari Bank

${ }^{32}$ Pasal 5 ayat (1) PBI Nomor 19/12/PBI/2017

${ }^{33}$ Pasal 5 ayat (2) PBI Nomor 19/12/PBI/2017.

Tata cara dan persyaratan dalam melakukan
Indonesia maupun dari kewenangan otoritas lain. ${ }^{33}$

Berikut ini adalah data sekunder mengenai Penyelenggara Teknologi Finansial yang telah melakukan kewajiban berupa pendaftaran dan telah dinyatakan lolos mengikuti Regulatory Sandbox per 18 September 2018:

\begin{tabular}{|c|c|c|c|}
\hline No & $\begin{array}{l}\text { Produk } \\
\text { (PLTM) }\end{array}$ & $\begin{array}{c}\text { Nama } \\
\text { Penyelengara }\end{array}$ & Keterangan \\
\hline 1. & $\begin{array}{l}\text { Cashlez } \\
\text { Mpos }\end{array}$ & $\begin{array}{l}\text { PT Cashlez } \\
\text { Worldwide } \\
\text { Indonesia }\end{array}$ & $\begin{array}{l}\text { Sistem } \\
\text { Pembayaran }\end{array}$ \\
\hline 2. & Pay by QR & $\begin{array}{l}\text { PT Dimo Pay } \\
\text { Indonesia }\end{array}$ & $\begin{array}{l}\text { Sistem } \\
\text { Pembayaran }\end{array}$ \\
\hline 3. & $\begin{array}{l}\text { Bayarind } \\
\text { Payment } \\
\text { Gateway }\end{array}$ & $\begin{array}{l}\text { PT Sprint } \\
\text { Asia } \\
\text { Technology }\end{array}$ & $\begin{array}{l}\text { Sistem } \\
\text { Pembayaran }\end{array}$ \\
\hline 4. & $\begin{array}{l}\text { Toko } \\
\text { Pandai }\end{array}$ & $\begin{array}{l}\text { PT Toko } \\
\text { Pandai } \\
\text { Nusantara }\end{array}$ & $\begin{array}{l}\text { Sistem } \\
\text { Pembayaran }\end{array}$ \\
\hline 5. & YoOk Pay & $\begin{array}{l}\text { PT Moneta } \\
\text { Digital } \\
\text { Internasional }\end{array}$ & $\begin{array}{l}\text { Sistem } \\
\text { Pembayaran }\end{array}$ \\
\hline 6. & Halomoney & $\begin{array}{l}\text { PT Money } \\
\text { Guru } \\
\text { Indonesia }\end{array}$ & $\begin{array}{l}\text { Pendukung } \\
\text { Pasar }\end{array}$ \\
\hline 7. & Duithape & $\begin{array}{l}\text { PT Virtual } \\
\text { Online } \\
\text { Exchange }\end{array}$ & $\begin{array}{l}\text { Sistem } \\
\text { Pembayaran }\end{array}$ \\
\hline 8 & Saldomu & $\begin{array}{l}\text { PT Mitra } \\
\text { Pembayaran } \\
\text { Elektronik }\end{array}$ & $\begin{array}{l}\text { Sistem } \\
\text { Pembayaran }\end{array}$ \\
\hline 9. & Disitu & $\begin{array}{l}\text { PT Gapura } \\
\text { Data Kreasi }\end{array}$ & $\begin{array}{l}\text { Pendukung } \\
\text { Pasar }\end{array}$ \\
\hline
\end{tabular}

pendaftaran kepada Bank Indonesia tercantum dalam pasal 7 PBI Nomor 19/12/PBI/2017 


\begin{tabular}{|c|c|c|c|}
\hline 10. & PajakPay & $\begin{array}{l}\text { PT Achilles } \\
\text { Financial } \\
\text { Systems }\end{array}$ & $\begin{array}{l}\text { Penyelengg } \\
\text { ara } \\
\text { Penunjang }\end{array}$ \\
\hline 11. & Wallezz & $\begin{array}{l}\text { PT Wallezz } \\
\text { Finansial } \\
\text { Teknologi }\end{array}$ & $\begin{array}{l}\text { Sistem } \\
\text { Pembayaran }\end{array}$ \\
\hline 12. & $\begin{array}{l}\text { Lead } \\
\text { Generation, } \\
\text { Credit } \\
\text { Scoring } \\
\text { Check, } \\
\text { Loan } \\
\text { Market } \\
\text { Place }\end{array}$ & $\begin{array}{l}\text { PT Trusting } \\
\text { Social } \\
\text { Indonesia }\end{array}$ & $\begin{array}{l}\text { Pendukung } \\
\text { Pasar }\end{array}$ \\
\hline 13. & Netzme & $\begin{array}{l}\text { PT Netzme } \\
\text { Kreasi } \\
\text { Indonesia }\end{array}$ & $\begin{array}{l}\text { Sistem } \\
\text { Pembayaran }\end{array}$ \\
\hline 14. & $\begin{array}{l}\text { Mareco- } \\
\text { Pay }\end{array}$ & $\begin{array}{l}\text { PT Mareco } \\
\text { Prima Mandiri }\end{array}$ & $\begin{array}{l}\text { Sistem } \\
\text { Pembayaran }\end{array}$ \\
\hline 15. & iPaymu & $\begin{array}{l}\text { PT Inti Prima } \\
\text { Mandiri } \\
\text { Utama }\end{array}$ & $\begin{array}{l}\text { Sistem } \\
\text { Pembayaran }\end{array}$ \\
\hline 16. & $\begin{array}{l}\text { Kanten } \\
\text { (KT-Pay) }\end{array}$ & $\begin{array}{l}\text { PT Aplikasi } \\
\text { Solusi Data } \\
\text { Indonesia }\end{array}$ & $\begin{array}{l}\text { Sistem } \\
\text { Pembayaran }\end{array}$ \\
\hline 17. & PrivyID & $\begin{array}{l}\text { PT Privy } \\
\text { Identitas } \\
\text { Digital }\end{array}$ & $\begin{array}{l}\text { Penyelengg } \\
\text { ara } \\
\text { Penunjang }\end{array}$ \\
\hline 18. & Emvazo & $\begin{array}{l}\text { PT } \\
\text { Monokrom } \\
\text { Digital } \\
\text { Teknologi } \\
\end{array}$ & $\begin{array}{l}\text { Sistem } \\
\text { Pembayaran }\end{array}$ \\
\hline 19. & OttoPay & $\begin{array}{l}\text { PT Reksa } \\
\text { Transaksi } \\
\text { Sukses } \\
\text { Makmur }\end{array}$ & $\begin{array}{l}\text { Sistem } \\
\text { Pembayaran }\end{array}$ \\
\hline 20. & SatuBon & $\begin{array}{l}\text { PT Indo } \\
\text { Sukses } \\
\text { Mandiri }\end{array}$ & $\begin{array}{l}\text { Sistem } \\
\text { Pembayaran }\end{array}$ \\
\hline 21. & OttoCash & $\begin{array}{l}\text { PT Transaksi } \\
\text { Artha } \\
\text { Gemilang }\end{array}$ & $\begin{array}{l}\text { Sistem } \\
\text { Pembayaran }\end{array}$ \\
\hline 22. & Paprika & $\begin{array}{l}\text { PT Paprika } \\
\text { Multi Media }\end{array}$ & $\begin{array}{l}\text { Sistem } \\
\text { Pembayaran }\end{array}$ \\
\hline
\end{tabular}

\begin{tabular}{|c|c|c|c|}
\hline 23. & $\begin{array}{l}\text { Celengan.I } \\
\mathrm{D}\end{array}$ & $\begin{array}{l}\text { PT Celengan } \\
\text { Inovasi } \\
\text { Keuangan }\end{array}$ & $\begin{array}{l}\text { Sistem } \\
\text { Pembayaran }\end{array}$ \\
\hline 24. & $\begin{array}{l}\text { Danaxtra.c } \\
\text { om }\end{array}$ & $\begin{array}{l}\text { PT Synergys } \\
\text { Lima }\end{array}$ & $\begin{array}{l}\text { Pendukung } \\
\text { Pasar }\end{array}$ \\
\hline 25 . & $\begin{array}{l}\text { Jaringaan } \\
\text { IDN \& } \\
\text { Sistem } \\
\text { IDN }\end{array}$ & $\begin{array}{l}\text { PT Infra } \\
\text { Digital } \\
\text { Nusantara }\end{array}$ & $\begin{array}{l}\text { Sistem } \\
\text { Pembayaran }\end{array}$ \\
\hline 26. & Davestpay & $\begin{array}{l}\text { PT Hensel } \\
\text { Davest } \\
\text { Indonesia }\end{array}$ & $\begin{array}{l}\text { Sistem } \\
\text { Pembayaran }\end{array}$ \\
\hline 27. & $\begin{array}{l}\text { Cermati.co } \\
\mathrm{m}\end{array}$ & $\begin{array}{l}\text { PT Dwi } \\
\text { Cermat } \\
\text { Indonesia }\end{array}$ & $\begin{array}{l}\text { Pendukung } \\
\text { Pasar }\end{array}$ \\
\hline 28. & EstaKios & $\begin{array}{l}\text { PT Esta } \\
\text { Digital Niaga }\end{array}$ & $\begin{array}{l}\text { Sistem } \\
\text { Pembayaran }\end{array}$ \\
\hline 29. & $\begin{array}{l}\text { Infinitium } \\
\text { Mobile } \\
\text { Secure, } \\
\text { Bank } \\
\text { Payment } \\
\text { Gateway, } \\
\text { dan } \\
\text { Infinitium } \\
\text { Mobile } \\
\text { eXperience }\end{array}$ & $\begin{array}{l}\text { PT Infinitium } \\
\text { Solutions }\end{array}$ & $\begin{array}{l}\text { Penyelengg } \\
\text { ara } \\
\text { Penunjang }\end{array}$ \\
\hline 30. & $\begin{array}{l}\text { Kreditgogo } \\
\text {.com }\end{array}$ & $\begin{array}{l}\text { PT Kredit } \\
\text { Gogo } \\
\text { Informatika }\end{array}$ & $\begin{array}{l}\text { Pendukung } \\
\text { Pasar }\end{array}$ \\
\hline 31. & Tupai & $\begin{array}{l}\text { PT Mitra } \\
\text { Pajakku }\end{array}$ & $\begin{array}{l}\text { Sistem } \\
\text { Pembayaran }\end{array}$ \\
\hline 32. & SwipePay & $\begin{array}{l}\text { PT First } \\
\text { Payment } \\
\text { Indonesia } \\
\end{array}$ & $\begin{array}{l}\text { Sistem } \\
\text { Pembayaran }\end{array}$ \\
\hline 33. & $\begin{array}{l}\text { Member } \\
\text { Card } \\
\text { Manageme } \\
\text { nt System } \\
\text { (MCMS) }\end{array}$ & $\begin{array}{l}\text { PT Prima } \\
\text { Vista Solusi }\end{array}$ & $\begin{array}{l}\text { Sistem } \\
\text { Pembayaran }\end{array}$ \\
\hline 34. & Easylife.id & $\begin{array}{l}\text { PT Tujuh } \\
\text { Insan } \\
\text { Solusindo }\end{array}$ & $\begin{array}{l}\text { Pendukung } \\
\text { Pasar }\end{array}$ \\
\hline
\end{tabular}

Tabel 1.

\section{Penyelenggara Teknologi Finansial \\ Terdaftar pada Bank Indonesia} Sumber: Bank Indonesia 
Hal ini berarti bahwa ke-34 Penyelenggara Teknologi Finansial (Fintech) tersebut yang telah terdaftar di Bank Indonesia telah memenuhi kriteria sebagai penyelenggara Teknologi Finansial (Fintech) di Indonesia berikut ${ }^{34}$ :

a. Menerapkan perlindungan sesuai dengan produk, layanan, teknologi, dan/atau model bisnis yang dijalankan Yang dimaksud dengan "menerapkan prinsip perlindungan konsumen" adalah penyelenggara Teknologi Finansial menerapkan prinsip sebagaimana diatur dalam ketentuan perundang-undangan yang mengatur mengenai perlindungan konsumen.

\section{b. Menjaga kerahasiaan data dan/atau informasi konsumen termasuk data dan/atau informasi transaksi \\ Menjaga kerahasiaan data} dan/atau informasi konsumen termasuk data dan/atau informasi transaksi antara lain dilakukan dengan mengelola dan menatausahakan dokumen transaksi dan/atau konsumen secara baik dan tertib serta tidak memberikan data dan/atau informasi transaksi dan/atau konsumen kepada pihak lain kecuali atas persetujuan tertulis

${ }^{34}$ Pasal 8 ayat (1) PBI Nomor 19/12/PBI/2017

35 Pasal 1 angka 1 UU No. 7 Tahun 2011 tentang Mata Uang dari konsumen atau diwajibkan oleh ketentuan peraturan perundangundangan.

\section{c. Menerapkan prinsip} manajemen risiko dan kehatihatian

Yang dimaksud dengan "menerapkan prinsip manajemen risiko" adalah penyelenggara Teknologi Finansial telah melakukan identifikasi, pengukuran, pemantauan, dan pengendalian atas risiko yang mungkin timbul dalam kegiatan usahanya.

\section{d. Menggunakan rupiah dalam setiap transaksi yang dilakukan di wilayah Negara Kesatuan Republik Indonesia sesuai dengan ketentuan peraturan perundang- undangan yang mengatur mengenai mata uang}

Penggunaan rupiah dalam setiap transaksi yang dilakukan di wilayah Negara Kesatuan Republik Indonesia sesuai dengan ketentuan dalam Undang-Undang Nomor 7 Tahun 2011 tentang Mata Uang. Dalam undang-undang ini disebutkan bahwa mata uang yang berlaku di Indonesia adalah Rupiah $^{35}$. Uang ini digunakan pulal sebagai alat pembayaran yang $\operatorname{sah}^{36}$.

\section{e. Menerapkan prinsip anti pencucian uang dan pencegahan pendanaan}

36 Pasal 1 angka 2 UU No. 7 Tahun 2011 tentang Mata Uang 


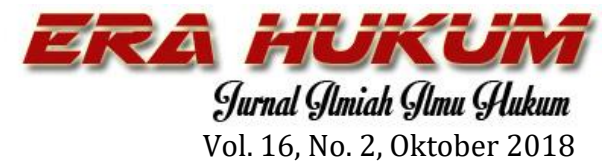

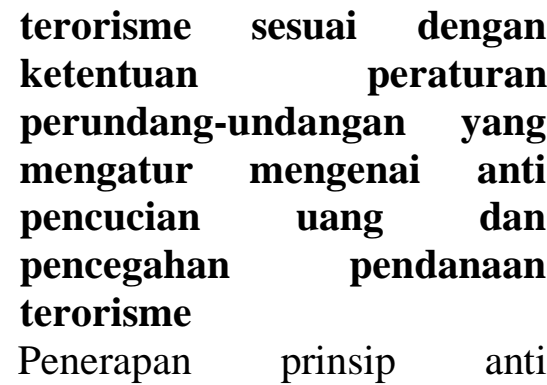
pencucian uang dan pencegahan pendanaan terorisme dilakukan sesuai dengan ketentuan peraturan perundang-undangan yang mengatur mengenai anti pencucian uang dan pencegahan pendanaan terorisme termasuk peraturan yang dikeluarkan oleh Lembaga pengawas dan pengatur yang terkait dengan kegiatan usaha dan/atau keberadaan dari penyelenggara Teknologi Finansial yang bersangkutan.

\section{f. Memenuhi ketentuan peraturan perundang- undangan lainnya}

Ketentuan peraturan perundang-undangan lain yang terkait adalah Undang-Undang Nomor 40 Tahun 2007 tentang Perseroan Terbatas dimana penyelenggara Teknologi Finansial pada umumnya adalah badan usaha berbentuk Perseroan Terbatas, Undang-Undang Nomor 11 Tahun 2008 tentang Informasi dan Transaksi Elektronik, UndangUndang Nomor 3 Tahun 2011 tentang Transfer Dana dan UndangUndang Nomor 7 Tahun 2011 tentang Mata Uang.

\footnotetext{
${ }^{37}$ Pasal 1 angka 4 PBI Nomor 19/12/PBI/2017
}

Selain itu, dari data sekunder Bank Indonesia juga terdapat data mengenai Penyelenggara Regulatory Sandbox Terdaftar per 18 September 2018:

\begin{tabular}{|c|c|l|l|}
\hline No & $\begin{array}{c}\text { Produk } \\
\text { (PLTM) }\end{array}$ & $\begin{array}{c}\text { Nama } \\
\text { Penyelenggara }\end{array}$ & Keterangan \\
\hline 1 & TokoPandai & $\begin{array}{l}\text { PT Toko } \\
\text { Pandai } \\
\text { Nusantara }\end{array}$ & $\begin{array}{l}\text { Penyelenggara } \\
\text { Penunjang }\end{array}$ \\
& & & \\
\hline
\end{tabular}

Tabel 2.

Penyelenggara Regulatory Sandbox

Terdaftar

Sumber: Bank Indonesia

Regulatory Sandbox adalah suatu ruang uji coba terbatas yang aman untuk menguji penyelenggara Teknologi Finansial beserta produk, layanan, teknologi, dan/atau model bisnisnya ${ }^{37}$. TokoPandai menyediakan ruang uji coba tersebut untuk memberi ruang bagi penyelenggara Teknologi Finansial untuk memastikan lebih lanjut bahwa produk, layanan, teknologi, dan/atau model bisnisnya telah memenuhi kriteria Teknologi 
Finansial sebagaimana tercantum dalam Pasal 3 ayat (2) PBI Nomor 19/12/PBI/2017 tersebut di atas, maka Bank Indonesia menyelenggarakan Regulatory Sandbox.

Penyelenggara Teknologi Finansial yang telah terdaftar di Bank Indonesia beserta produk, layanan, teknologi, dan/atau model bisnisnya diuji coba dalam Regulatory Sandbox. ${ }^{38}$ Bank Indonesia menetapkan jangka waktu tertentu bagi penyelenggara Teknologi Finansial untuk melakukan uji coba dalam Regulatory Sandbox tersebut. Setelah jangka waktu tersebut berakhir, Bank Indonesia menetapkan statur hasil uji coba penyelenggara Teknologi Finansial berupa ${ }^{39}$ :

a. Berhasil

b. Tidak Berhasil

c. Status lain yang ditetapkan Bank Indonesia

Dalam hal uji coba dinyatakan berhasil dan produk, layanan, teknologi, dan/atau model bisnisnya termasuk Teknologi Finansial kategori sistem pembayaran maka

\footnotetext{
${ }^{38}$ Pasal 11 ayat (3) PBI Nomor 19/12/PBI/2017
}

penyelenggara Teknologi Finansial dilarang memasakna produk, layanan, teknologi, dan/atau model bisnis yang diujicobakan sebelum terlebih dahulu mengajukan permohonan izin dan/atau persetujuan sesuai dengan ketentuan Bank Indonesia yang mengatur mengenai penyelenggaraan pemrosesan transaksi pembayaran.

Dalam hal uji coba dinyatakan tidak berhasil dan produk, layanan, teknologi dan/atau model bisnisnya termasuk Teknologi Finansial kategori sistem pembayaran maka penyelenggara Teknologi Finansial dilarang memasarkan produk dan/atau layanan serta menggunakan teknologi dan/atau model bisnis yang diujicobakan.

Dalam hal produk, layanan, teknologi, dan/atau model bisnisnya termasuk Teknologi Finansial selalin kategori sistem pembayaran, Bank Indonesia dapat menyampaikan status hasil uji coba penyelenggara Teknologi

\footnotetext{
${ }^{39}$ Pasal 12 ayat (2) PBI Nomor 19/12/PBI/2017
} 


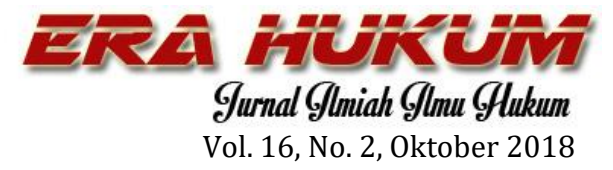

Finansial kepada otoritas yang berwenang

Selama proses uji coba dalam Regulatory Sandbox, Bank Indonesia dapat menetapkan kebijakan tertentu bagi penyelenggara Teknologi Finansial. Penetapan kebijakan tertentu dilakukan dengan memperhatikan karakteristik produk, layanan, teknologi, dan/atau model bisnis yang diuji coba. ${ }^{40}$

\section{Urgensi dan Batasan Pengaturan Teknologi Finansial (Fintech) di Masa yang Akan Datang (Ius Constituendum)}

"Disruptive era" menandai dimasukinya era Revolusi 4.0. Era dimana masyarakat dan pemerintah dihadapkan pada teknologi yang mendisrupsi kemapanan termasuk di dalamnya kemapanan hukum bisnis, baik business to business maupun business to consumer, seperti yang

40 Pasal 13 PBI Nomor 19/12/PBI/2017. Ketentuan lebih lanjut mengenai Regulatory Sandbox diatur dalam Peraturan Anggota Dewan Gubernur. dikemukakan dalam kolom Opini Kompas tahun lalu:

"Teknologi telah mengubah kehidupan kita dan mendisrupsi kemapanan berbagai sektor industri” ${ }^{41}$

Era disrupsi ini termasuk pula dalam hukum bisnis, baik business to business maupun business to consumer khususnya mengenai Teknologi Finansial (Fintech). Era ini merupakan era spesial sehingga perlu dihadapi dengan cara yang spesial pula, seperti perenungan di bawah ini:

"Having arrived at the end of our journey through the world of emerging and disruptive technologies, it's worth examining where we stand in the current evolution of information technology and how the next several years may impact our business. The outstanding question is whether or not the next five years will be as dramatic as the past five years in terms of the highs and lows of our expectations, business objectives and realities, and economic forecasts. We also need to know whether the next five years will bring increased business

${ }^{41}$ Junanto Herdiawan, "Teknologi Finansial dan Masa Depan Perbankan”, Kompas, 21 Februari 2017, 6 
productivity from the application of technology or whether the gains have already been accomplished. Is the internet technology wave just starting or has it already peaked? What were the lessons learned over the past several years and how can these be applied moving forward? Where can new forms of value be extracted and how should an organization position itself to gain competitive advantage? What is the next killer application and what is the timing of consumer and enterprise adoption?"42

Era Revolusi Industri 4.0 merupakan era dimana kita dihadapkan dengan "fundamental technological change", seperti dikemukakan oleh Klaus Schwab, Pendiri sekaligus Ketua World Economic Forum, dalam Bukunya "The Fouth Industrial Revolution" sebagai berikut:

"We live in exciting times of fundamental technological change.

The pace and scope of groundbreaking scientific and

42 Nicholas Evans, Business Innovation and Disruptive Technology: Harnessing the Power of Breakthrough Technology for Competitive Advantage, (New Jersey: Financial Times Prentice Hall, 2003), 159

43 Klaus Schwab, The Fourth Industrial Revolution, (London: Penguin, 2017), vii

44 Bagas Setiaji, Direktorat Pengaturan, Perizinan dan Pengembangan Teknologi Finansial pada Otoritas Jasa Keuangan (OJK) technological advances coming from research facilities, star-ups and large organizations never cease to amaze me. The "science fiction" of yesterday is today becoming a reality in new products and services that won't be able to imagine having lived without." 43

Oleh karena Teknologi Finansial (Fintech) semakin berkembang dari hari ke hari, maka diperlukan penyesuaian dengan bentukan hukum terkini untuk meregulasi secara teknis mengenai Teknologi Finansial (Fintech). OJK sejauh ini berperan untuk melakukan pengawasan Teknologi Finansial (Fintech), sekaligus meregulasi peer-to-peerlending ${ }^{44}$. Selain itu, telah dibentuk pula BSSN yang bersama dengan Kementerian Komunikasi dan Informatika (Kemkominfo) bertugas melaksanakan keamanan siber secara

Republik Indonesia, Jakarta, 16 Oktober 2018. Baca juga Satjipto Rahardjo, "Hukum Itu Perangkat Keras Juga”, Kompas, 6 Oktober 1986. Baca juga Shidarta, "Hukum Sebagai Sistem Nilai Dalam Perspektif Perkembangan Ilmu Pengetahuan dan Teknologi”, Era Hukum: Jurnal Ilmiah Ilmu Hukum, No. 2 Tahun 1, Oktober 1994. 
efektif dan efisien dengan memanfaatkan, mengembangkan dan mengonsolidasikan semua unsur yang terkait dengan keamanan siber nasional. ${ }^{45}$ BSSN menyusun Strategi Keamanan Siber Indonesia sebagai acuan bersama seluruh pemangku kepentingan keamanan siber nasional dalam menyusun dan mengembangkan kebijakan keamanan siber di instansi masing-masing. ${ }^{46}$

Selanjutnya, berkaitan dengan era disrupsi, sistem nilai sebagai kontrol terhadap progresivitas Teknologi Finansial (Fintech) di Indonesia perlu diperkuat. Pengaturan Teknologi Finansial (Fintech) merupakan hal yang penting, tetapi lebih penting lagi pengontrolan mengenai kesesuaiannya dengan kultur hukum bangsa Indonesia. Peraturan yang sejatinya

${ }^{45}$ Badan Siber dan Sandi Negara,

"Strategi Keamanan Nasional", https://bssn.go.id/strategi-keamanan-sibernasional/, diakses pada tanggal 6 Agustus 2018

${ }^{46}$ Loc. Cit. Badan Siber dan Sandi Negara (BSSN) yang didirikan berdasarkan Peraturan Presiden (Perpres) Republik Indonesia Nomor 53 Tahun 2017 tentang Badan Siber dan Sandi Negara sebagaimana diubah dengan Peraturan Presiden Nomor 133 Tahun 2017 tentang Perubahan Atas Peraturan Presiden Nomor 53 adalah bentuk tanggapan pemerintah terhadap manfaat Teknologi Finansial (Fintech) yang terbukti membawa manfaat bagi masyarakat. Manfaat yang kemudian ditangkap dan dibentuk dalam suatu bingkai peraturan dengan pemilahan terlebih dahulu mengenai bagian Teknologi Finansial (Fintech) mana yang dapat diterima dan tidak dapat diterima oleh kultur hukum bangsa Indonesia.

\section{F. Penutup}

Berikut ini kesimpulan dan saran dari penelitian ini:

\section{Kesimpulan}

Manfaat yang diterima oleh masyarakat merupakan faktor utama yang menyebabkan progresivitas

Tahun 2017 tentang hal yang sama. Lembaga tersebut berada langsung di bawah dan bertanggung jawab kepada presiden. Sebelumnya, Lembaga itu berada di bawah Menteri Koordinator Politik, Hukum dan Keamanan. Joko Widodo, Presiden Republik Indonesia melantik Mayor Jenderal Djoko Setiadi sebagai Kepala BSSN. BSSN merupakan Lembaga yang menggabungkan fungsi Lembaga Sandi Negara (Lemsaneg) dengan Direktorat Keamanan Kementerian Komunikasi dan Informasi (Kemkominfo). 
Teknologi Finansial dalam Hukum

Bisnis di Indonesia baik business to business maupun business to consumer. Progresivitas tersebut terwujud dengan diaturnya Teknologi Finansial (Fintech) dalam PBI Nomor 19/12/PBI/2017. Hal ini terkait dengan Teori Hukum Progresif terutama mengenai bagaimana hukum melayani lingkungan yang berubah akibat adanya beragam manfaat dari Teknologi Finansial (Fintech).

Jika dilihat dari sudut pandang Teori Sociological Jurisprudence, penyebab (cause) dari munculnya peraturan (rule) mengenai Teknologi Finansial (Fintech) tersebut tertuang dalam urgensi maupun pertimbangan dari PBI Nomor 19/12/PBI/2017. Urgensi dari PBI Nomor 19/12/PBI/2017 tersebut terdiri atas 4 (empat) hal yang menjadi urgensi Teknologi Financial (Fintech) secara spesifik yaitu: (1) mendorong alokasi sumber daya ekonomi secara lebih efisien; (2) mendorong peningkatan produktivitas serta memberikan manfaat yang lebih besar bagi masyarakat melalui digitalisasi ekonomi; (3) sebagai konsekuensi dari semakin diadopsinya Teknologi Finansial oleh masyarakat; dan (4) memitigasi berkembangnya transaksi perekonomian yang tidak terawasi (shadow economy).

Sedangkan pertimbangan dari dari PBI Nomor 19/12/PBI/2017 tersebut adalah Teknologi Financial (Fintech) muncul untuk menjawab kebutuhan dari: (1) masyarakat; (2) pemerintah; (3) dan pertumbuhan ekonomi nasional. Dari pihak masyarakat terdapat kebutuhan akan akses terhadap layanan finansial dan pemrosesan transaksi. Dari pihak pemerintah, dalam hal ini Bank Indonesia terdapat kepentingan mitigasi risiko agar perkembangan Teknologi Finansial (Fintech) tidak mengganggu sistem keuangan. Selanjutnya, terkait dengan pertumbuhan ekonomi nasional, Teknologi Finansial (Fintech) perlu terus dimonitor dan dikembangkan.

Kedua elemen, baik urgensi maupun pertimbangan yang tercantum dalam PBI Nomor 19/12/PBI/2017 tersebut menyiratkan perhatian 
pemerintah terhadap kebutuhan

masyarakat akan Teknologi Finansial (Fintech).

\section{Saran}

Berkaitan dengan bentukan hukum Teknologi Finansial (Fintech) di masa yang akan datang (ius constituendum), perlu diadakan penyesuaian dengan perkembangan Teknologi Finansial (Fintech) di masa yang akan datang dengan sistem nilai dan peraturan yang ada di Indonesia. Selama produk dari Teknologi Finansial (Fintech) tersebut tidak bertentangan dengan sistem nilai yang ada, maka produk Teknologi Finansial (Fintech) tersebut dapat dikembangkan dan diatur penyelenggaraannya di Indonesia.

\section{Daftar Pustaka}

\section{Buku dan Book Chapter}

Evans, Nicholas. Business Innovation and Disruptive Technology: Harnessing the Power of Breakthrough Technology for Competitive Advantage. New Jersey: Financial Times Prentice Hall, 2003.
Denzin, N.K. dan Y. S. Lincoln. Handbook of Qualitative Research Research. London: Sage, 1994.

Freedman, Roy S. Introduction to Financial Technology. London: Elsevier Inc, 2006.

Pound, Roscoe. An Introduction to the Philosophy of Law. London: Universal Law Publishing Company Pvt. Limited, 2008.

Raharjo, Satjipto. Membedah Hukum Progresif. Jakarta: Penerbit Buku Kompas, 2006.

Schwab, Klaus. The Fourth Industrial Revolution. London: Penguin, 2017.

Schwandt, Thomas A. "Three Epistemological Stances for Qualitative Theory" dalam Norman K Denzin dan Yvonna S Lincoln (ed). Handbook of Qualitative Research. London, Sage 2000. Soemitro, Ronny Hanitjo. Metodologi Penelitian Hukum. Jakarta: Ghalia Indonesia, 1982.

Safitri, Myrna. Satjipto Rahardjo dan Hukum Progresif: Urgensi dan Kritik. Jakarta: Epistema Institute, 2011.

\section{Jurnal}

Magnuson, William. "Regulating Fintech". Vanderbilt Law Review. Vol. 71 Issue 4, Tahun 2018. 
Loo, Rory Van. "Making Innovation More Competitive". UCLA Law Review. Vol. 65 Issue 1 Tahun 2018.

Shidarta. "Hukum Sebagai Sistem Nilai Dalam Perspektif Perkembangan Ilmu Pengetahuan dan Teknologi”. Era Hukum: Jurnal Ilmiah Ilmu Hukum, No. 2 Tahun 1. Oktober 1994.

Tu, Kevin V. "Regulating the New Cashless World". Alabama Law Review. Vol. 65 Issue 1, Tahun 2013.

Vasant, Dhar dan Roger Stein. "FinTech Platforms and Strategy: Integrating Trust and Automation in Finance". Communications of the ACM. Vol. 60 Issue 10, Tahun 2017. Varga, David. "FinTech, The New Era of Financial Services". Budapest Management Review. Vol. 48 Issue 11, Tahun 2017.

Walker, George. "Financial Technology Law: A New Beginning and A New Future". GPSolo. Vol. 34 Issue 3, Tahun 2017.

Koran

Herdiawan, Junanto. "Teknologi Finansial dan Masa Depan Perbankan". Kompas. 21 Februari 2017.
Rahardjo, Satjipto. "Hukum Itu Perangkat Keras Juga". Kompas. 6 Oktober 1986.

\section{Peraturan Perundang-undangan}

Undang-Undang No. 7 Tahun 2011 tentang Mata Uang

Peraturan Bank Indonesia Nomor 19/12/PBI/2017

Peraturan Presiden Nomor 133 Tahun 2017 tentang Perubahan Atas Peraturan Presiden Nomor 53 Tahun 2017 tentang Badan Siber dan Sandi Negara

\section{Internet}

Amirullah, "Jokowi Lantik Djoko Setiadi Sebagai Kepala BSSN", https://nasional.tempo.co/read /1046906/jokowi-lantikdjoko-setiadi-sebagai-kepalabssn, diakses pada tanggal 6 Agustus 2018.

Chaerudin, Asep, "Strategi Keamanan Siber Nasional", https://bssn.go.id/strategikeamanan-siber-nasional/, diakses pada tanggal 6 Agustus 2018

Kementerian Komunikasi dan Informatika, "Indonesia akan jadi pemain ekonomi digital terbesar di Asia”. https://www.kominfo.go.id/co ntent/detail/6441/indonesiaakan-jadi-pemain-ekonomidigital-terbesar-di-asia- 
tenggara/0/berita_satker, diakses pada tanggal 28 Juli 2018.

\section{Wawancara}

Setiaji, Bagas. Direktorat Pengaturan,

Perizinan dan Pengembangan

Teknologi Finansial pada Otoritas

Jasa Keuangan (OJK) Republik

Indonesia. Jakarta, 16 Oktober 2018. 